\title{
Pengaruh Profitabilitas, Likuiditas, Leverage, dan Ukuran Perusahaan Terhadap Kebijakan Dividen Saham-saham yang Terdaftar pada Jakarta Islamic Index (JII) Periode Tahun 2011-2015
}

\author{
Rika Dwi Ayu Parmitasari* \& Hasrianto
}

\begin{abstract}
Dividend policy becomes an important financial policy, not only from the company management side, but also from shareholders. Shareholders will apply for dividends if the company makes a profit. The growth of the Jakarta Islamic Index industry which tends to be good and stable earnings will be easier and focused to see profitability, liquidity, leverage, and firm size affect dividend payout ratio and of course dividend payout ratio. Based on the statement can be seen that investors want a stable dividend policy. However, in fact, the average growth of dividend payout ratio during the period 2010-2015 fluctuated and did not indicate the implementation of a stable dividend policy. This study aims to obtain empirical evidence about the influence of profitability, liquidity, leverage, and size of the company against dividend policy. The approach taken in this research is quantitative approach.

Sample selection method in this study is purposive sampling is the method of selecting the sample by using some certain criteria so that get 11 samples of companies listed in the Jakarta Islamic Index period of 2011-2015, which amounted to 30 companies. The analysis method used is financial analysis, classical assumption test, multiple regression analysis, coefficient of determination, $F$ test and $t$ test.

The results of this study indicate that the variables of profitability, liquidity, leverage and firm size affect simultaneously to dividend policy. Partial test shows that the variable profitability, liquidity, and size of the company have a positive and significant impact on dividend policy. Meanwhile, leverage has a negative and insignificant effect on dividend policy. The coefficient of determination showed 59.9\%. These results indicate the ability of independent variables in explaining the dependent variable while $40.1 \%$ is explained by other variables. The results of this study can provide information or as a signal to the public and outside parties or investors to take investment decisions and assess the financial performance of a company.
\end{abstract}

Keywords: Profitability, Liquidity, Leverage, Company Size and Dividend Policy

\section{A. Latar Belakang Masalah}

Kebijakan dividen merupakan bagian dari keputusan pendanaan (Van Horne and Wachowicz, 2005:270). Kebijakan dividen merupakan suatu keputusan mengenai pembagian laba perusahaan. Kebijakan dividen merupakan suatu keputusan yang sulit bagi pihak manajemen perusahaan. Pembagian dividen di satu sisi akan memenuhi harapan investor untuk mendapatkan return sebagai hasil dari investasinya, sedangkan di satu sisi pembagian dividen diharapkan tidak mengancam kelangsungan hidup perusahaan. Manajemen perusahaan sebaiknya dapat membuat suatu kebijakan dividen yang optimal berarti kebijakan tersebut

\footnotetext{
* Jurusan Manajemen Fakultas Ekonomi dan Bisnis Islam UIN Alauddin Makassar: (rparmitasari@uin-alauddin.ac.id)
} 
harus menghasilkan semacam keseimbangan antara kepentingan pemegang saham melalui dividen dan kepentingan perusahaan dalam hal pertumbuhannya. Kebijakan dividen akan memengaruhi nilai perusahaan dan nilai perusahaan penting dimata investor (Parmitasari, 2016).

Investor dan pihak manajemen seringkali memiliki kepentingan yang berbeda. Pihak manajemen cenderung mengutamakan kepentingan pribadinya, dimana hal tersebut tidak disukai oleh pihak investor. Pihak investor menganggap bahwa kepentingan pribadi dari pihak manajemen akan mengurangi tingkat keuntungan yang diperoleh perusahaan. Perbedaan kepentingan seperti ini seringkali menimbulkan konflik, yang disebut dengan konflik keagenan. Konflik keagenan bisa dikurangi dengan berbagai mekanisme, salah satunya adalah dengan kebijakan dividen. Menyangkut mengenai pendapatan berupa dividen, investor lebih menyukai dividen yang stabil karena hal tersebut akan meningkatkan kepercayaan investor terhadap perusahaan yang bersangkutan (Sandy dan Asyik, 2013).

Kebijakan dividen ke para pemegang saham dapat ditentukan dengan Dividend Payout Ratio (DPR) merupakan hasil pembagian dividen per lembar saham dengan laba bersih per saham. Kebijakan dividen ditentukan dalam Rapat Umum Pemegang Saham (RUPS), yang membahas mengenai laba dibagikan ke pemegang saham dalam bentuk dividen atau laba yang dihasilkan perusahaan tidak dibagikan guna ekspansi perusahaan. Perusahaan yang mempunyai laba yang besar membagi dividen kepada pemegang saham setiap tahun tergantung kebijakan yang ditetapkan suatu perusahaan (Bambang Riyanto, 2001). Dalam menentukan kebijakan dividen, perlu dipertimbangkan faktor kinerja perusahaan melalui rasio keuangan. Penelitian ini menggunakan rasio profitabilitas, likuiditas, leverage dan ukuran perusahaan.

Profitabilitas merupakan kemampuan suatu perusahaan dalam memperoleh laba. Laba perusahaan tersebut akan menjadi acuan dalam pembayaran dividennya. Besarnya tingkat laba akan mempengaruhi besarnya tingkat pembayaran dividen yang dibagikan kepada pemegang saham. Rasio ini mengukur efektivitas manajemen secara keseluruhan yang ditujukan oleh besar kecilnya tingkat keuntungan yang diperoleh dalam hubungannya dengan penjualan maupun investasi. Semakin baik rasio profitabilitas maka semakin baik menggambarkan kemampuan tingginya perolehan keuntungan perusahaan (Irham Fahmi, 2012:80).

Return on assets (ROA) merupakan pengembalian investasi. Rasio ini melihat sejauh mana investasi yang telah ditanamkan mampu memberikan pengembalian keuntungan sesuai dengan yang diharapkan (Irham Fahmi, 2012:82) Pihak manajemen akan membayarkan dividen untuk memberi sinyal mengenai keberhasilan perusahaan membukukan profit. Sinyal tersebut menyimpulkan bahwa kemampuan perusahaan untuk membayar dividen merupakan fungsi dari keuntungan. Aljannah (2010), Kuwari (2010), Moradi dan Honarmand (2009) menemukan variabel profitabilitas berpengaruh positif dan signifikan terhadap kebijakan dividen. Hasil yang berbeda di temukan oleh Sunarto (2004).

Likuiditas merupakan kemampuan perusahaan dalam memenuhi kewajiban jangka pendeknya dengan tepat waktu. Bagi perusahaan, dividen adalah arus kas 
keluar, dan hal tersebut mempengaruhi posisi dari kas perusahaan. Hal tersebut mengakibatkan kesempatan perusahaan dalam melakukan investasi menggunakan kas yang dibagikan dalam bentuk dividen tersebut berkurang (Suharli, 2006). Perusahaan yang memiliki likuiditas yang baik akan mampu membayar dividen yang lebih banyak, dibandingkan dengan perusahaan yang mempunyai likuiditas kurang atau tidak baik. Likuiditas perusahaan sangat berpengaruh terhadap perusahaan dalam memperoleh laba dan dibayarkan dalam bentuk dividen kepada pemegang saham. Laba tersebut akan digunakan perusahaan untuk mendanai investasi atau dibayarkan dalam bentuk dividen. Semakin likuid sebuah perusahaan, kemungkinan pembayaran dividen yang dilakukan perusahaan tersebut akan semakin besar. Likuiditas berpengaruh positif dan signifikan ditemukan oleh Wicaksana (2012) dan Andriyani (2008). Hasil yang berbeda ditemukan oleh Novatiani dan Oktaviani (2012).

Kinerja keuangan lainnya yaitu Leverage, mencerminkan perusahaan dalam memenuhi seluruh kewajibannya yang ditunjukkan oleh beberapa bagian modal sendiri yang digunakan untuk membayar hutang (Rodoni dan Ali, 2010:123). Asimetri informasi menyebabkan pendanaan ekternal terlalu mahal bagi perusahaan, karena itu perusahaan lebih memprioritaskan dana internal daripada ekternal. Apabila dana internal tidak mencukupi, maka perusahaan dituntut untuk melakukan pendanaan ekternal yang biasanya lebih mengutamakan pendanaan utang daripada saham. Sehingga leverage perusahaan digunakan untuk pembayaran dividen agar dapat menjaga performa dan signal perusahaan bagi investor (Indah Sulistiyowati, 2010). Leverage berpengaruh negatif dan signifikan ditemukan Dewi (2008), Lopulusi (2013), Jannati (2010), Marlina dan Danica (2009). Hasil yang berbeda ditemukan oleh Danang dan Sunindyo (2010), Mahadwartha dan Jogiyanto (2002).

Perusahaan dengan ukuran yang besar cenderung memiliki suatu kemudahan dalam aksesnya menuju pasar modal. Tentu saja hal tersebut mempengaruhi fleksibilitas perusahaan besar tersebut dalam memperoleh dana dalam jumlah besar. Perolehan dana tersebut, dapat digunakan sebagai pembayaran dividen bagi pemegang sahamnya. Semakin besar tingkat ukuran suatu perusahaan, kemungkinan tingkat pembayaran dividen akan semakin besar pula. Zou et al. (2008), (2012), dan Imran (2011) serta Hermuningsih (2007) menemukan hasil variabel size berpengaruh positif signifikan terhadap kebijakan dividen. Hasil yang berbeda yakni, ukuran perusahaan berpengaruh negatif tidak signifikan ditemukan oleh Jeong (2011), Arif dan Akbar (2013), Ahmed dan Javid (2008) serta Novatiani dan Oktaviani (2012).

Berikut ini data rata-rata Dividend Payout Ratio (DPR), Return On Assets (ROA), Current Ratio (CR), Debt to Equity Ratio (DER), dan Size Tahun 2011 sampai tahun 2015 yang diambil dari 11 perusahaan yang konsisten terdaftar pada Jakarta Islamic Index (JII). Data adalah sebagai berikut: 
Tabel 1.1 Data DPR, ROA, CR, DER, dan Size di Jakarta Islamic Index (JII)

Tahun 2011-2015.

\begin{tabular}{|c|c|c|c|c|c|}
\hline \multirow{2}{*}{ Tahun } & \multicolumn{5}{|c|}{ Variabel } \\
\cline { 2 - 6 } & DPR & ROA & CR & DER & Size \\
\hline 2011 & $53.90 \%$ & $22.94 \%$ & $301.57 \%$ & $0.55 \%$ & $15.37 \%$ \\
\hline 2012 & $56.72 \%$ & $20.57 \%$ & $273.09 \%$ & $0.63 \%$ & $15.51 \%$ \\
\hline 2013 & $69.71 \%$ & $19.82 \%$ & $245.61 \%$ & $0,65 \%$ & $15.61 \%$ \\
\hline 2014 & $51.51 \%$ & $15.66 \%$ & $215.84 \%$ & $0.67 \%$ & $30.26 \%$ \\
\hline 2015 & $54.17 \%$ & $12.42 \%$ & $212.62 \%$ & $0.71 \%$ & $15.74 \%$ \\
\hline
\end{tabular}

Sumber: Annual Report IDX Tahun 2011-2015 (diolah).

Berdasarkan Tabel 1.1 dapat dilakukan analisis sementara pengaruh variabelvariabel bebas terhadap kebijakan dividen. Analisis sementara tersebut untuk mengetahui konsistensi pengaruh profitabilitas, likuiditas, leverage, dan ukuran perusahaan yang diperkirakan berpengaruh positif atau negatif terhadap kebijakan dividen.

Dapat dilihat bahwa kebijakan dividen yang diukur dengan Dividend Payout Ratio (DPR) mengalami peningkatan dari tahun 2011-2013, di tahun 2014 mengalami penurunan namun di tahun 2015 DPR kembali mengalami peningkatan. Hal ini menunjukkan bahwa naik turunnya tingkat persentasi laba yang dapat dinikmati oleh para investor dari tahun 2011 sampai tahun 2015.

Tahun 2011-2012 ROA mengalami penurunan, ROA mengalami peningkatan dari tahun 2012-2013 begitupun dengan DPR ikut meningkat. Tahun 2013-2015 ROA mengalami penurunan namun DPR kembali meningkat di tahun 2014-2015. Fenomena ini tidak sesuai dengan pernyataan Nugroho (2010), bahwa kemampuan perusahaan dalam memperoleh keuntungan merupakan faktor utama dalam penentuan tingkat pembayaran dividen perusahaan kepada pemegang saham.

Adanya kemungkinan tingkat likuiditas yang memengaruhi DPR, ini terlihat dari penurunan Current Ratio secara konsisten dari tahun 2011-2015. Nilai DPR ditahun 2014 sebesar 51.51\% yang merupakan presentasi terendah dari tahun 20112015 sedangkan presentasi terendah Current Ratio terjadi pada tahun 2015 sebesar $212.62 \%$. Ini terbukti bahwa salah satu faktor yang mempengaruhi kebijakan dividen adalah tingkat likuiditas.

Pada variabel Debt to Equity Ratio terjadi fenomena pada tahun 2011-2015 nilai Debt to Equity Ratio tetap konsisten mengalami peningkatan setiap tahun, sedangkan nilai DPR hanya mengalami penigkatan pada tahun 2011-2013 dan mengalami peenurunan dari tahun 2013-2014 dengan nilai sebesar 51.51\%. Namun kembali terjadi peningkatan dari tahun 2014-2015 dengan nilai sebesar $54.17 \%$. Fenomena ini bertentangan dengan teori yang menyatakan bahwa semakin tinggi leverage suatu perusahaan, tingkat pembayaran dividen juga akan semakin rendah.

Pada variabel Size kembali terjadi fenomena pada tahun 2011-2014 nilai Size mengalami peningkatan setiap tahun. Namun ditahun 2015 Size mengalami penurunan dengan nilai sebesar $15.74 \%$. Sedangkan DPR hanya mengalami peningkatan di tahun 2011-2013. DPR mengalami penurunan pada tahun 2014 
dengan nilai sebesar 51.51\%, namun kembali meningkat di tahun 2015 dengan nilai sebesar $54.17 \%$. Fenomena ini bertentangan dengan teori yang menyatakan bahwa semakin besar nilai ukuran suatu perusahaan, tingkat pembayaran dividen juga akan semakin besar.

\section{B. Rumusan Masalah}

Berdasarkan pada latar belakang penelitian yang telah disampaikan, maka rumusan masalah penelitian ini adalah sebagai berikut:

1. Apakah profitabilitas, likuiditas, leverage, dan ukuran perusahaan berpengaruh secara simultan terhadap kebijakan dividen?

2. Apakah profitabilitas berpengaruh terhadap kebijakan dividen?

3. Apakah likuiditas berpengaruh terhadap kebijakan dividen?

4. Apakah leverage berpengaruh terhadap kebijakan dividen ?

5. Apakah ukuran perusahaan berpengaruh terhadap kebijakan dividen?

\section{Hipotesis}

Hipotesis dari penelitian ini adalah sebagai berikut:

1. $\mathrm{H}_{1}$ : Diduga Profitabilitas likuiditas, leverage, dan ukuran perusahaan berpengaruh secara simultan terhadap kebijakan dividen.

2. $\mathrm{H}_{2}$ : Diduga Profitabilitas berpengaruh positif dan signifikan terhadap kebijakan dividen.

3. $\mathrm{H}_{3}$ : Diduga likuiditas berpengaruh positif dan sinifikan terhadap kebijakan dividen.

4. $\mathrm{H}_{4}$ : Diduga leverage berpengaruh negatif dan tidak signifikan terhadap kebijakan dividen.

5. $\mathrm{H}_{5}$ : Diduga ukuran perusahaan berpengaruh positif dan signifikan terhadap kebijakan dividen

\section{TINJAUAN TEORITIS}

\section{A. Kebijakan Dividen}

1. Pengertian Kebijakan Dividen

Kebijakan dividen adalah kebijakan yang berhubungan dengan pembayaran dividen oleh pihak perusahaan, berupa penentuan besarnya pembayaran dividen dan besarnya laba ditahan untuk kepentingan pihak perusahaan. Jika manajemen meningkatkan porsi laba per lembar saham yang dibayarkan sebagai dividen, maka mereka dapat meningkatkan kesejahteraan para pemegang saham, hal ini menyarankan bahwa keputusan dividen yaitu jumlah dividen yang dibayarkan merupakan suatu hal yang sangat penting. Kebijakan dividen adalah kebijakan yang menentukan jumlah dividen relatif terhadap laba bersih perusahaan atau penghasilan per saham (Keown, dkk, 2005). Dari pengertian kebijakan dividen di atas, maka dapat disimpulkan bahwa kebijakan dividen merupakan rencana pembagian pendapatan yang harus diikuti dalam membuat keputusan dividen, apakah dividen akan dibayarkan atau ditahan dalam perusahaan sebagai laba ditahan.

2. Teori Kebijakan Dividen 
Menurut Brigham dan Houston (2001:14) menyebutkan ada tiga teori dari preferensi investor yaitu:

a. Dividend irrelevance theory

Dividend irrelevance theory adalah suatu teori yang menyatakan bahwa kebijakan dividen tidak mempunyai pengaruh, baik terhadap nilai perusahaan maupun biaya modalnya. Teori ini mengikuti pendapat Modigliani dan Miller (MM) yang menyatakan bahwa nilai suatu perusahaan tidak ditentukan oleh besar kecilnya Dividend Payout Ratio (DPR) tetapi ditentukan oleh laba bersih sebelum pajak (EBIT) dan risiko bisnis. Dengan demikian kebijakan dividen sebenarnya tidak relevan untuk dipersoalkan.

b. Bird in the hand Theory

Menurut Gordon dan Litner (1956), tingkat keuntungan yang disyaratkan akan naik apabila pembagian dividen dikurangi karena investor lebih yakin terhadap penerimaan dividen daripada kenaikan nilai modal (capital gain) yang akan dihasilkan dari laba ditahan. Pendapat Gordon dan Litner (1956) oleh MM diberi nama bird in the hand fallacy. Gordon dan Litner beranggapan investor memandang bahwa satu burung di tangan lebih berharga daripada seribu burung di udara. Namun, MM berpendapat bahwa tidak semua investor berkepentingan untuk menginvestasikan kembali dividen mereka di perusahaan yang sama dengan memiliki resiko yang sama, oleh sebab itu tingkat resiko pendapatan mereka di masa yang akan datang bukannya ditentukan oleh DPR tetapi ditentukan oleh tingkat resiko investasi baru.

c. Tax preference theory

Tax preference theory adalah suatu teori yang menyatakan bahwa karena adanya pajak terhadap keuntungan dividen dan capital gains maka para investor lebih menyukai capital gains karena dapat menunda pembayaran pajak. Karenanya pilihan ini menjadi penanda pilihan para investor.

\section{B. Teori Keagenan (Agency Theory)}

Teori ini dikemukakan oleh Michael C. Jensen dan Wiliam H. Meckling (1976:305), hubungan agensi muncul ketika satu orang atau lebih (principal) mempekerjakan orang lain (agent) untuk memberikan suatu jasa dan kemudian mendelegasikan wewenang dalam pengambilan keputusan kepada agent tersebut. Dalam prakteknya manajer sebagai pengelola perusahaan tentunya mengetahui lebih banyak informasi internal dan prospek perusahaan di waktu mendatang dibandingkan pemilik modal atau pemegang saham. Sehingga sebagai pengelola, manajer memiliki kewajiban memberikan informasi mengenai kondisi perusahaan kepada pemilik.

Para pemegang saham berharap agen akan bertindak atas kepentingan mereka sehingga mendelegasikan wewenang kepada agen. Untuk dapat melakukan fungsinya dengan baik, manajemen harus diberikan insentif dan pengawasan yang memadai. Pengawasaan dapat dilakukan melalui cara-cara seperti pengikatan agen, pemeriksaan laporan keuangan dan pembatasaan terhadap keputusan yang dapat diambil manajemen. Kegiatan pengawasaan tentu saja membutuhkan biaya yang disebut dengan biaya agensi. Biaya agensi adalah biaya-biaya yang 
berhubungan dengan pengawasan manajemen untuk meyakinkan bahwa manajemen bertindak konsisten sesuai dengan perjanjian kontraktual perusahaan dengan kreditor dan pemegang saham (Chasanah, 2008).

\section{Dividend Payout Ratio (DPR)}

Dividend Payout Ratio (DPR) adalah persentase laba yang dibayarkan dalam bentuk dividen, atau rasio antara laba yang dibayarkan dalam bentuk dividen dengan total laba yang tersedia bagi pemegang saham (Agus Sartono, 2001). Semakin besar dividend payout ratio yang dibagikan, maka akan semakin kecil dana yang yang ditahan oleh perusahaan dan sebaliknya semakin kecil dividend payout ratio yang dibagikan, maka semakin besar laba yang ditahan oleh perusahaan.

\section{Profitabilitas}

Menurut Rodoni dan Ali (2010:123) profitabilitas adalah kemampuan perusahaan memperoleh laba dalam hubungannya dengan penjualan, total aset maupun modal sendiri. Dengan demikian bagi investor jangka panjang akan sangat berkepentingan dengan analisis profitabilitas ini misalnya bagi pemegang saham akan melihat keuntungan yang benar-benar akan diterima dalam bentuk dividen. Faktor profitabilitas juga berpengaruh terhadap kebijakan dividen karena dividen adalah laba bersih yang diperoleh perusahaan, oleh karena itu dividen akan dibagikan apabila perusahaan memperoleh keuntungan. Keuntungan yang layak dibagikan kepada pemegang saham adalah keuntungan setelah perusahaan memenuhi kewajiban-kewajiban tetapnya yaitu bunga dan pajak. Dari laba setelah pajak tersebut sebagian dibagikan sebagai dividen kepada para pemegang saham dan sebagian lain ditahan di perusahaan (laba ditahan). Jika laba yang diperoleh kecil, maka dividen yang akan dibagikan juga kecil (Syariati, 2012).

\section{E. Likuiditas}

Likuiditas merupakan kemampuan perusahaan memenuhi semua kewajibannya yang jatuh tempo. Kemampuan itu dapat diwujudkan bila jumlah harta lancar lebih besar dari hutang lancar. Perusahaan yang likuid adalah perusahaan yang tidak mampu memenuhi kewajibannya yang jatuh tempo (Darsono,2009). Perusahaan yang tidak likuid akan kehilangan kepercayaan dari pihak luar terutama para kreditur dan pemasok, dan dari pihak dalam yaitu karyawan. Oleh sebab itu perusahaan harus memiliki likuiditas yang baik. Aset Likuid (liquid assests) merupakan asset yang diperdagangkan di pasar aktif sehingga dapat dikonversi dengan cepat menjadi kas pada harga pasar yang berlaku, sedangkan "posisi likuiditas" suatu perusahaan berkaitan dengan kemampuan perusahaan melunasi utang ketika jatuh tempo di tahun berikutnya. Suatu analisis likuiditas penuh membutuhkan penggunaan arus kas, tetapi dengan menghubungkan kas dengan asset lancar lainnya dengan kewajiban lancar, analisis rasio memberikan ukuran likuiditas yang cepat dan mudah digunakan. 


\section{F. Leverage}

Rasio ini mencerminkan kemampuan perusahaan dalam memenuhi seluruh kewajibannya yang ditunjukkan oleh beberapa bagian modal sendiri yang digunakan untuk membayar hutang (Prihantoro, 2003). Semakin besar rasio ini menunjukkan semakin besar kewajibannyaa dan rasio yang semakin rendah akan menunjukkan semakin tinggi kemampuan perusahaan memenuhi kewajibannya. Apabila menentukan bahwa pelunasan utangnya akan diambilkan dari laba ditahan, berarti perusahaan harus menahan sebagian besar dari pendapatannya untuk keperluan tersebut, yang ini berarti hanya sebagian kecil saja pendapatan yang dapat dibayarkan sebagai dividen (Riyanto,2001). Peningkatan utang ini akan mempengaruhi tingkat pendapatan bersih yang tersedia bagi pemegang saham, artinya semakin tinggi kewajiban perusahaan, akan semakin menurunkan kemampuan perusahaan membayar dividen (Sudarsi, 2002).

\section{G. Ukuran Perusahaan}

Perusahaan yang besar cenderung mempunyai akses yang lebih mudah dalam pasar modal. Hal tersebut akan mengurangi ketergantungan mereka pada pendanaan internal, sehingga perusahaan akan memberika pembayaran dividen yang tinggi (Hatta, 2002). Perusahaan besar cenderung membagikan dividen yang lebih besar daripada perusahaan kecil, karena perusahaan yang memiliki aset besar lebih mudah memsuki pasar modal. Sedangkan perusahaan yang memiliki aset sedikit akan cenderung membagikan dividen yang rendah karena laba dialokasikan pada laba ditahan untuk menamba aset perusahaan (Chang dan Ree, 1990).

Perusahaan yang memiliki aset besar cenderung membayar dividen yang besar kepada pemegang saham untuk menjaga reputasi di kalangan investor (Nuringsih, 2005). Menurut Sujoko (2007) ukuran perusahaan yang besar menunjukkan perusahaan mengalami perkembangan sehingga investor akan merespon positif dan nilai perusahaan akan meningkat. Pangsa pasar relatif menunjukkan daya saing perusahaan lebih tinggi dibanding pesaing utamanya. Investor akan merespon positif sehingga nilai perusahaan akan meningkat. Hartono (2000) menyatakan ukuran perusahaan sebagai logaritma dari total aktiva diprediksi mempunyai hibungan negatif dengan risiko, dia juga menghipotesiskan bahwa perusahaan besar cenderung berivestai ke proyek yang mempunyai varian rendah dan risiko yang rendah, untuk menghindari laba yang berlebihan.

\section{METODE PENELITIAN}

Jenis penelitian yang digunakan adalah penelitian asosiatif. Penelitian asosiatif merupakan suatu penelitian yang bertujuan untuk mengetahui hubungan antara dua variabel atau lebih, antara variabel independen/terikat dan variabel dependent/bebas (Sugiyono 20012). Lokasi Penelitian ini dilakukan pada perusahaan yang konsisten terdaftar di Bursa Efek Indonesia khususnya yang tergabung dalam dalam Jakarta Islamic Index (JII) pada tahun 2011-2015. Waktu penelitian selama 2 bulan yaitu pada bulan Januari sampai bulan Maret 2017.

Variabel independen pada penelitian ini antara lain: Profitabilitas (X1), Likuiditas (X2), Leverage (X3), Ukuran Perusahaan (X4), dan variabel dependen yaitu 
Kebijakan Dividen $(Y)$. Jenis data dalam penelitian ini adalah data kuantitatif berupa data sekunder yang bersumber dari laporan keuangan perusahaan. Dalam penelitian ini sumber data diambil dari laporan keuangan tahunan perusahaan yang terdaftar di Jakarta Islamic Index (JII) tahun 2011-2015, jurnal-jurnal penelitian sebelumnya, website yang berkaitan dengan penelitian.

Populasi yang digunakan dalam penelitian ini sebanyak 30 perusahaan dan Sampel dalam penelitian ini sebanyak 11 perusahaan yang terdaftar di Bursa Efek Indonesia yang tergabung dalam Jakarta Islamic Index (JII) dari Tahun 2011-2015. Penarikan sampel yang dilakukan adalah dengan menggunakan desain sampel berupa metode purposive sampling dimana dilakukan pemilihan sampel berdasarkan penilaian terhadap beberapaa karakteristik anggota populasi yang disesuaaikan dengan maksud penelitian (Mudrajad kuncoro, 2003).

Kriteria sampel yang digunakan oleh peneliti antara lain: 1) Perusahaan harus konsisten terdaftar di Jakarta Islamic Index (JII) selama tahun 2011-2015, 2) Perusahaan harus konsisten dalam membagikan dividen selama tahun 2011-2015, 3) Melampirkan laporan keuangan tahun 2011-2015.

Metode pengumpulan data berupa data sekunder dari laporan keuangan perusahaan dari tahun 2011-2015. Data ini diperoleh dari situs www.idx.com atau dari situs perusahaan yang masuk dalam sampel penelitian. Pengimputan data menggunakan bantuan program Microsoft Excel 2010 for Windows dan pengujian hipotesis menggunakan bantauan program SPSS 21.00 for Windows.

Teknik analisis data yang digunakan anatara lain: 1) analisis keuangan, 2) Uji asumsi klasik meliputi uji normalitas, uji multikolienaritas, uji heteroskedestisitas, dan uji autokorelasi, 3) Analisis regresi berganda, 4) Koefisien Determinasi R2, 5) Uji hipotesis meliputi uji t dan uji F.

\section{HASIL PENELITIAN DAN PEMBAHASAN}

\section{A. Analisis Keuangan}

1. Analisis Kebijakan Dividen (Dividend Payout Ratio)

Tabael 4.1 Hasil Perhitungan Kebijakan Deviden (Dividend Payout Ratio)

Perusahaan yang Konsisten Terdaftar di Jakarta Islamic Index 2011-2015

\begin{tabular}{|c|l|c|c|c|c|c|}
\hline \multirow{2}{*}{ No. } & \multicolumn{1}{|c|}{ Nama Perusahaan } & \multicolumn{5}{|c|}{ Dividend payout ratio (\%) } \\
\cline { 3 - 7 } & & $\mathbf{2 0 1 1}$ & $\mathbf{2 0 1 2}$ & $\mathbf{2 0 1 3}$ & $\mathbf{2 0 1 4}$ & $\mathbf{2 0 1 5}$ \\
\hline 1 & PT. Astra International Tbk. & 45.07 & 45.03 & 45.04 & 45.59 & 49.54 \\
\hline 2 & $\begin{array}{l}\text { PT. Charoen Pokphand } \\
\text { Indonesia Tbk. }\end{array}$ & 29.24 & 28.10 & 29.80 & 16.90 & 25.89 \\
\hline 3 & $\begin{array}{l}\text { PT. Indocement Tunggal } \\
\text { Perkasa Tbk. }\end{array}$ & 29.99 & 34.80 & 66.13 & 94.29 & 35.07 \\
\hline 4 & $\begin{array}{l}\text { PT. IndoTambangraya Megah } \\
\text { Tbk. }\end{array}$ & 53.30 & 84.65 & 210.99 & 79.19 & 99.26 \\
\hline 5 & PT. Kalbe Farma Tbk. & 65.09 & 66.77 & 44.97 & 43.14 & 44.44 \\
\hline 6 & $\begin{array}{l}\text { PT. PP London Sumatera } \\
\text { Indonesia Tbk. }\end{array}$ & 40.10 & 40.34 & 40.79 & 39.45 & 40.5 \\
\hline 7 & PT. Tambang Batubara Bukit & 60.03 & 57.26 & 58.29 & 37.09 & 32.79 \\
\hline
\end{tabular}




\begin{tabular}{|c|l|c|c|c|c|c|}
\hline & Asam Tbk. & & & & & \\
\hline 8 & PT. Semen Gresik (Persero) Tbk. & 50.00 & 45.00 & 45.00 & 40.00 & 40.00 \\
\hline 9 & $\begin{array}{l}\text { PT. Telekomunikasi Indonesia } \\
\text { (Persero) Tbk. }\end{array}$ & 68.22 & 68.42 & 72.66 & 61.29 & 61.59 \\
\hline 10 & PT. United Tractors Tbk. & 51.83 & 53.57 & 53.25 & 64.95 & 66.89 \\
\hline 11 & PT. Unilever Indonesia Tbk & 100.06 & 99.96 & 99.93 & 44.67 & 99.88 \\
\hline$\quad$ Total & 592.93 & 623.9 & 766.85 & 566.56 & 595.85 \\
\hline \multicolumn{2}{|c|}{ Rata-rata } & 53.90 & 56.72 & 69.71 & 51.51 & 54.17 \\
\hline
\end{tabular}

Sumber: Data Ringkasan Kinerja Laporan Keuangan Perusahaan

Berdasarkan tabel 4.1 di atas menunjukkan bahwa jumlah data yang digunakan dalam penelitian ini adalah sebanyak 55 sampel data yang diambil dari laporan keuangan perusahaan yang terdafatar secara konsisten dalam Jakarta Islamic Index pada tahun 2011-2015. Kebijakan dividen yang diukur dengan Dividen Payout Ratio menunjukkan bahwa naik turunnya presentasi laba yang dapat dinikmati oleh investor dari tahun 2011 sampai dengan tahun 2015. PT. Indocement Tunggal Perkasa Tbk mengalami peningkatan Dividen Payout Ratio dari tahun 20112014, ini di karenakan perusahaan mampu mengatur likuiditas dengan baik selama empat tahun terakhir, namun ditahun 2015 perusahaan tidak mampu mempertahankan po sisi likuiditas dengan baik sehingga pembayaran dividen pun ikut mengalami penurunan.

PT. Unilever Indonesia Tbk nilai Dividen Payout Ratio yang mengalami penurunan secara konsisten dari tahun 2011 hingga 2015, ini membuktikan bahwa perusahaan ini mempunyai kebutuhan dana yang besar dalam membayar hutang melalui dari pendapatan perusahaan yang ditahan mengakibatkan rendahnya dividen yang akan dibayarkan kepada para pemegang saham. Posisi likuiditas yang kurang baik mengakibatkan dividen juga turun, karena semakin lemahnya posisi kas maka mengakibatkan dividen yang dibayarkan kepada pemegang saham menurun.

2. Analisis Profitabilitas (Return On Asset)

Tabel 4.2 Hasil Perhitungan Profitabilitas (Return On Asset) Perusahaan yang Konsisten Terdaftar di Jakarta Islamic Index 2011-2015

\begin{tabular}{|c|l|c|c|c|c|c|}
\hline \multirow{2}{*}{ No. } & \multicolumn{1}{|c|}{ Nama Perusahaan } & \multicolumn{5}{|c|}{ Return On Asset (\%) } \\
\cline { 3 - 7 } & & $\mathbf{2 0 1 1}$ & $\mathbf{2 0 1 2}$ & $\mathbf{2 0 1 3}$ & $\mathbf{2 0 1 4}$ & $\mathbf{2 0 1 5}$ \\
\hline 1 & PT. Astra International Tbk. & 13.73 & 12.48 & 10.42 & 9.37 & 6.36 \\
\hline 2 & $\begin{array}{l}\text { PT. Charoen Pokphand } \\
\text { Indonesia Tbk. }\end{array}$ & 26.7 & 21.71 & 16.08 & 8.37 & 7.42 \\
\hline 3 & $\begin{array}{l}\text { PT. Indocement Tunggal } \\
\text { Perkasa Tbk. }\end{array}$ & 19.48 & 20.93 & 18.84 & 18.26 & 15.76 \\
\hline 4 & $\begin{array}{l}\text { PT. IndoTambangraya } \\
\text { Megah Tbk. }\end{array}$ & 34.60 & 28.97 & 16.56 & 15.31 & 5.36 \\
\hline 5 & PT. Kalbe Farma Tbk. & 18.41 & 18.85 & 17.41 & 17.07 & 15.02 \\
\hline 6 & $\begin{array}{l}\text { PT. PP London Sumatera } \\
\text { Indonesia Tbk. }\end{array}$ & 25.05 & 14.77 & 9.64 & 10.59 & 7.04 \\
\hline 7 & PT. Tambang Batubara Bukit & 26.83 & 22.86 & 15.88 & 13.63 & 12.06 \\
\hline
\end{tabular}




\begin{tabular}{|c|l|c|c|c|c|c|}
\hline & Asam Tbk. & & & & & \\
\hline 8 & $\begin{array}{l}\text { PT. Semen Gresik (Persero) } \\
\text { Tbk. }\end{array}$ & 20.12 & 18.54 & 17.39 & 16.24 & 11.86 \\
\hline 9 & $\begin{array}{l}\text { PT. Telekomunikasi } \\
\text { Indonesia (Persero) Tbk. }\end{array}$ & 15.01 & 16.49 & 15.86 & 15.22 & 14.03 \\
\hline 10 & PT. United Tractors Tbk. & 12.7 & 11.44 & 8.37 & 8.03 & 4.52 \\
\hline 11 & PT. Unilever Indonesia Tbk & 39.73 & 40.38 & 71.58 & 40.18 & 37.20 \\
\hline$\quad$ Total & 246.67 & 205.71 & 218.03 & 172.27 & 136.63 \\
\hline$\quad$ Rata-rata & 22.94 & 20.57 & 19.82 & 15.66 & 12.42 \\
\hline
\end{tabular}

Sumber: Data Ringkasan Kinerja Laporan Keuangan Perusahaan.

Berdasarkan tabel 4.2 di atas menunjukkan bahwa rata- rata besarnya Return On Asset tahun 2011-2015 pada perusahaan yang tergabung dalam Jakarta Islamic Index berbeda-beda dari tahun ke tahun. Pada tahun 2011 rata- rata Return On Asset yang paling tinggi yaitu sebesar 22,94\%. Pada tahun 2012-2015, mengalami penurunan masing-masing sebesar 20,27\%, 19,82\%, 15,66\% dan 12,42\%. Rasio profitabilitas perusahaan yang diukur dengan Return On Asset selama tahun 2011, 2012, 2013, 2014, dan 2015 yang paling besar yaitu PT. Unilever Tbk sebesar 39,73\%, 40,38\%, 71,51\%, 40,18\% dan 37,2\% disebabkan perusahaan makin efektif dalam memanfaatkan aset untuk menghasilkan laba bersih dan laba usaha mengalami kenaikan seiring peningkatan pendapatan operasional perusahaan dari semua basis bisnis.

PT. Unilever Indonesia merupakan salah satu perusahaan yang memiliki saham syariah yang mencatat pertumbuhan yang sangat baik dari tahun ke tahun. Keberhasilan ini adalah buah dari strategi yang menyeluruh di sepanjang rantai nilai perusahaan. Unilever telah tumbuh menjadi perusahaan terdepan untuk produk home and personal care serta foods \& Ice Cream di Indonesia. Rangkaian Produk Unilever Indonesia mencakup brand-brand ternama yang disukai di dunia. Sedangkan rasio profitabilitas yang paling rendah yaitu PT. Astra internasional Tbk pada setiap periodenya 2010-2015 sebesar 13,73\%, 12,48\%, 10,42\%, 9,37\% dan 6,36\% disebabkan kenaikan suku bunga dan tindakan Bank Indonesia mengatur skema pembelian diperkirakan akan berdampak pada penjualan dipengaruhi perkembangan harga bahan baku, fluktuasi nilai tukar rupiah, dan persaingan industri yang kompetitif.

3. Analisis Likuiditas (Current Ratio)

Tabel 4.3 Hasil Perhitungan Likuiditas (Current Ratio) Perusahaan yang Konsisten Terdaftar di Jakarta Islamic Index 2011-2015

\begin{tabular}{|c|l|c|c|c|c|c|}
\hline \multirow{2}{*}{ No. } & \multicolumn{1}{|c|}{ Nama Perusahaan } & \multicolumn{5}{|c|}{ Current Ratio (\%) } \\
\cline { 3 - 7 } & & $\mathbf{2 0 1 1}$ & $\mathbf{2 0 1 2}$ & $\mathbf{2 0 1 3}$ & $\mathbf{2 0 1 4}$ & $\mathbf{2 0 1 5}$ \\
\hline 1 & PT. Astra International Tbk. & 136.4 & 139.91 & 124.2 & 132.26 & 137.93 \\
\hline 2 & $\begin{array}{l}\text { PT. Charoen Pokphand } \\
\text { Indonesia Tbk. }\end{array}$ & 333.23 & 331.28 & 379.23 & 224.07 & 210.62 \\
\hline 3 & $\begin{array}{l}\text { PT. Indocement Tunggal } \\
\text { Perkasa Tbk. }\end{array}$ & 698.54 & 602.76 & 614.81 & 459.75 & 488.66 \\
\hline
\end{tabular}




\begin{tabular}{|c|l|c|c|c|c|c|}
\hline 4 & $\begin{array}{l}\text { PT. IndoTambangraya Megah } \\
\text { Tbk. }\end{array}$ & 236.59 & 221.71 & 199.19 & 156.40 & 180.18 \\
\hline 5 & PT. Kalbe Farma Tbk. & 365.27 & 340.54 & 283.93 & 340.36 & 369.78 \\
\hline 6 & $\begin{array}{l}\text { PT. PP London Sumatera } \\
\text { Indonesia Tbk. }\end{array}$ & 483.25 & 327.3 & 248.52 & 249.11 & 222.10 \\
\hline 7 & $\begin{array}{l}\text { PT. Tambang Batubara Bukit } \\
\text { Asam Tbk. }\end{array}$ & 463.25 & 492.37 & 286.59 & 207.51 & 154.35 \\
\hline 8 & $\begin{array}{l}\text { PT. Semen Gresik (Persero) } \\
\text { Tbk. }\end{array}$ & 264.65 & 170.59 & 188.24 & 220.90 & 159.70 \\
\hline 9 & $\begin{array}{l}\text { PT. Telekomunikasi } \\
\text { Indonesia (Persero) Tbk. }\end{array}$ & 95.80 & 116.04 & 116.31 & 106.32 & 135.29 \\
\hline 10 & PT. United Tractors Tbk. & 171.64 & 194.65 & 191.02 & 206.04 & 214.77 \\
\hline 11 & PT. Unilever Indonesia Tbk & 68.67 & 66.83 & 69.64 & 71.49 & 65.40 \\
\hline \multicolumn{1}{|c|}{ Total } & 3317.29 & 3003.98 & 2701.68 & 2374.21 & 2338.78 \\
\hline \multicolumn{2}{|c|}{ Rata-rata } & 301.57 & 273.08 & 245.61 & 215.84 & 212.62 \\
\hline
\end{tabular}

Sumber: Data Ringkasan Kinerja Laporan Keuangan Perusahaan.

Berdasarkan tabel 4.3 di atas menunjukkan bahwa likuiditas yang diukur dengan Current Ratio perusahaan yang terdaftar secara konsisten dalam Jakarta Islamic Index tahun 2011-2015 mengalami peningkatan dan penurunan atau berfluktuasi. Rata-rata Current Ratio tertinggi terjadi pada tahun 2011 dengan nilai sebesar 301.57\%. Hal ini membuktikan bahwa pada tahun 2011 perusahaanperusahaan yang tergabung dalam Jakarta Islamic Index tergolong likuid artinya perusahaan tersebut mampu membayar utang jangka pendeknya. Selain itu pada tahun 2012-2015 rata-rata Current Ratio mengalami penurunan setiap tahun dengan nilai rmasing-masing 273,08\%,245,61\%,215,84\%, dan 212,62\%. Hal ini terjadi karena perusahaan tergolong tidak likuid artinya perusahaaan tidak mampu membayar utang jangka pendeknya.

4. Analisis Leverage (Debt to Equity Ratio)

Tabel 4.4 Hasil Perhitungan Leverage (Debt to quity Ratio) Perusahaan yang Konsisten Terdaftar di Jakarta Islamic Index 2011-2015

\begin{tabular}{|c|l|c|c|c|c|c|}
\hline \multirow{2}{*}{ No. } & \multicolumn{1}{|c|}{ Nama Perusahaan } & \multicolumn{5}{|c|}{ Debt to Equity Ratio (\%) } \\
\cline { 3 - 7 } & & $\mathbf{2 0 1 1}$ & $\mathbf{2 0 1 2}$ & $\mathbf{2 0 1 3}$ & $\mathbf{2 0 1 4}$ & $\mathbf{2 0 1 5}$ \\
\hline 1 & PT. Astra International Tbk. & 1,02 & 1.03 & 1.02 & 0.96 & 0.94 \\
\hline 2 & $\begin{array}{l}\text { PT. Charoen Pokphand Indonesia } \\
\text { Tbk. }\end{array}$ & 0.43 & 0.51 & 0.58 & 0.91 & 0.97 \\
\hline 3 & $\begin{array}{l}\text { PT. Indocement Tunggal Perkasa } \\
\text { Tbk. }\end{array}$ & 0.15 & 0.17 & 0.16 & 0.17 & 0.16 \\
\hline 4 & \begin{tabular}{l} 
PT. IndoTambangraya Megah Tbk. \\
\hline 5
\end{tabular} & 0.46 & 0.49 & 0.45 & 0.44 & 0.41 \\
\hline 6 & $\begin{array}{l}\text { PT. Kalbe Farma Tbk. } \\
\text { PT. PP London Sumatera Indonesia } \\
\text { Tbk. }\end{array}$ & 0.27 & 0.28 & 0.33 & 0.27 & 0.25 \\
\hline 7 & $\begin{array}{l}\text { PT. Ta mbang Batubara Bukit Asam } \\
\text { Tbk. }\end{array}$ & 0.41 & 0.50 & 0.20 & 0.20 & 0.21 \\
\hline
\end{tabular}




\begin{tabular}{|c|l|c|c|c|c|c|}
\hline 8 & PT. Semen Gresik (Persero) Tbk. & 0.35 & 0.46 & 0.41 & 0.37 & 0.39 \\
\hline 9 & $\begin{array}{l}\text { PT. Telekomunikasi Indonesia } \\
\text { (Persero) Tbk. }\end{array}$ & 0.69 & 0.66 & 0.65 & 0.64 & 0.78 \\
\hline 10 & PT. United Tractors Tbk. & 0.67 & 0.56 & 0.61 & 0.56 & 0.57 \\
\hline 11 & PT. Unilever Indonesia Tbk & 1.85 & 2.02 & 2.14 & 2.11 & 2.26 \\
\hline \multicolumn{2}{r|}{ Total } & 5.48 & 6.88 & 7.11 & 7.34 & 7.76 \\
\hline Rata-rata & 0.55 & 0.63 & 0.65 & 0.67 & 0.71 \\
\hline
\end{tabular}

Sumber: Data Ringkasan Kinerja Laporan Keuangan Perusahaan.

Berdasarkan tabel 4.4 di atas menunjukkan bahwa rata- rata besarnya leverage pada tahun 2011-2015 pada perusahaan yang tergabung dalam Jakarta Islamic Index berbeda-beda dari tahun ke tahun artinya mengalami fluktuasi. Pada tahun 2011 mempunyai rata- rata besarnya Debt to Equity Ratio yakni sebesar 0,55\%. Pada tahun 2012-2015, mengalami peningkatan setiap tahun masing-masing sebesar 0,63\%, $0,65 \%, 0,67 \%$ dan $0,71 \%$.

Rasio leverage perusahaan yang diukur dengan Debt to Equity Ratio selama tahun 2011, 2012, 2013, 2014, dan 2015 yang yang memiliki nilai paling besar yaitu PT. Unilever Tbk sebesar 1,85\%, 2,02\%, 2,14\%, 2,11\% dan 22,26\%. Hal ini dikarenakan komitmen perusahaan di sektor manufaktur untuk melakukan pembayaran dividen tidak teratur menyebabkan leverage perusahaan meningkat setiap tahun. Peningkatan hutang akan mempengaruhi tingkat pendapatan bersih yang tersedia bagi para pemegang saham, artinya semakin tinggi hutang perusahaan, maka akan semakin menurunkan kemampuan perusahaan dalam membayar dividen (Deitiana, 2009). Berbeda dengan perusahaan PT. PP London sumatera Indonesia Tbk yang memiliki nilai leverage yang paling rendah dari tahun 2011-2105 dengan nilai masing-masing setiap tahun yaitu $0,2 \%, 0,2 \%, 0,21 \%, 0,2 \%$ dan $0,21 \%$. Hal ini disebabkan perusahaan mampu melakukan pembayaran dividen secara teratur meskipun leverage menggambarkan gejala yang kurang baik bagi perusahaan namun dengan menyeimbangkan pendapatan bersih yang tersedia dengan pelunasan hutang akan mempermudah perusahaan dalam pembayaran dividen.

5. Analisis Ukuran Perusahaan (Size)

Tabel 4.5 Hasil Perhitungan Ukuran perusahaan (Size) Perusahaan yang Konsisten Terdaftar di Jakarta Islamic Index 2011-2015

\begin{tabular}{|c|l|c|c|c|c|c|}
\hline No. & \multicolumn{1}{|c|}{ Nama Perusahaan } & \multicolumn{5}{|c|}{ Size (\%) } \\
\cline { 3 - 7 } & & $\mathbf{2 0 1 1}$ & $\mathbf{2 0 1 2}$ & $\mathbf{2 0 1 3}$ & $\mathbf{2 0 1 4}$ & $\mathbf{2 0 1 5}$ \\
\hline 1 & PT. Astra International Tbk. & 11.95 & 12.11 & 12.27 & 12.37 & 12.41 \\
\hline 2 & $\begin{array}{l}\text { PT. Charoen Pokphand Indonesia } \\
\text { Tbk. }\end{array}$ & 16.1 & 16.33 & 16.57 & 16.85 & 17.02 \\
\hline 3 & $\begin{array}{l}\text { PT. Indocement Tunggal Perkasa } \\
\text { Tbk. }\end{array}$ & 16.71 & 16.94 & 17.10 & 17.18 & 17.13 \\
\hline 4 & PT. IndoTambangraya Megah Tbk. & 14.27 & 14.22 & 14.10 & 14.08 & 13.38 \\
\hline 5 & PT. Kalbe Farma Tbk. & 15.93 & 16.06 & 16.24 & 16.34 & 16.43 \\
\hline 6 & PT. PP London Sumatera & 15.73 & 15.84 & 15.89 & 17.59 & 16.10 \\
\hline
\end{tabular}




\begin{tabular}{|c|l|c|c|c|c|c|}
\hline & Indonesia Tbk. & & & & & \\
\hline 7 & $\begin{array}{l}\text { PT. Tambang Batubara Bukit Asam } \\
\text { Tbk. }\end{array}$ & 16.26 & 16.36 & 16.27 & 16.51 & 16.64 \\
\hline 8 & PT. Semen Gresik (Persero) Tbk. & 16.79 & 17.1 & 17.24 & 17.35 & 17.46 \\
\hline 9 & $\begin{array}{l}\text { PT. Telekomunikasi Indonesia } \\
\text { (Persero) Tbk. }\end{array}$ & 11.54 & 11.62 & 11.76 & 11.86 & 12.02 \\
\hline 10 & PT. United Tractors Tbk. & 17.65 & 17.73 & 17.87 & 17.91 & 17.94 \\
\hline 11 & PT. Unilever Indonesia Tbk & 16.71 & 16.3 & 16.41 & 16.47 & 16.57 \\
\hline \multicolumn{2}{|}{ Total } & 169.1 & 170.61 & 171.72 & 332.82 & 173.1 \\
\hline \multicolumn{2}{|l}{ Rata-rata } & 15.37 & 15.51 & 15.61 & 30.26 & 15.74 \\
\hline
\end{tabular}

Sumber: Data Ringkasan Kinerja Laporan Keuangan Perusahaan.

Berdasarkan tabel 4.5 di atas menunjukkan bahwa ukuran perusahaan yang dihitung dengan logaritma natural dari total aktiva perusahaan pada tahun 20112015 mengalami peningkatan dan penurunan atau berfluktuasi. Rata-ukuran perusahaan yang paling tinggi terjadi pada tahun 2014 dengan nilai sebesar 30,26\% dan rata-rata paling rendah terjadi pada tahun 2011 dengan nilai sebesar 15,37\%. Adanya perubahan nilai ukuran perusahaan disetiap tahun disebabkan oleh keadaan perekonomian yang belum begitu stabil, sehingga pengelolaan dana yang dilakukan oleh perusahaan dalam menjalankan usahanya belum efektif. Laba yang dihasilkan pun tidak maksimal. Keadaan yang demikian membuat baik perusahaan kecil maupun besar akan lebih berorientasi pada pertumbuhan perusahaannya (Ayu idawati dan Sudartha, 2014).

Pada tahun 2011-2015 ukuran perusahaan (Size) tertinggi dimiliki PT. United Tractors Tbk dengan nilai masing-masing sebesar 17,65\%, 17,73\%, 17,87\% , 17,91\% dan 17,97\% lebih besar dari nilai rata-rata tahun 2011-2015 sebesar 15,37\%, 15,51\%, 15,61\%, 30,26\%, dan 15,74\%. Ukuran perusahaan (Size) terendah dimiliki PT. Asrta Internasional Tbk dengan nilai sebesar 11.95\%, 12,1\%, 12,27\%, 12,37\% dan 12,41\% lebih kecil dari nilai rata-rata Size pada tahun 2011-2015 dengan keadaan perusahaan tidak membayar dividen.

\section{B. Hasil Uji Asumsi Klasik}

1. Hasil Uji Normalitas

Tabel 4.6 Hasil Uji Normalitas

One-Sample Kolmogorov-Smirnov Test

\begin{tabular}{|ll|r|}
\hline & & $\begin{array}{r}\text { Unstandardized } \\
\text { Residual }\end{array}$ \\
\hline $\mathrm{N}$ & Mean & 55 \\
Normal Parameters ${ }^{\mathrm{a}, \mathrm{b}}$ & Std. & .0000000 \\
& Deviation & .36897222 \\
Most Extreme & Absolute & .147 \\
Differences & Positive & .147 \\
Kolmogorov-Smirnov Z & Negative & -.088 \\
\end{tabular}


Asymp. Sig. (2-tailed)

a. Test distribution is Normal.

b. Calculated from data.

Sumber: SPSS 21 (Data dio;ah 2017)

Berdasarkan Output SPSS pada uji Kolmogrov-Smirnov diatas menunjukkan bahwa nilai signifikan (Asymp.Sig. 2-tailed) sebesar 0,188 lebih besar dari 0,05. Sehingga dapat disimpulkan bahwa nilai residual pada penelitian yang diuji telah berdistribusi normal.

2. Hasil Uji Multikolienaritas

Tabel 4.7 Hasil Uji Multikolienaritas

Coefficients ${ }^{\mathrm{a}}$

\begin{tabular}{|c|c|c|c|c|c|c|c|}
\hline \multirow[t]{2}{*}{ Model } & \multicolumn{2}{|c|}{$\begin{array}{l}\text { Unstandardi } \\
\text { zed } \\
\text { Coefficients }\end{array}$} & \multirow{2}{*}{\begin{tabular}{|c}
$\begin{array}{c}\text { Standardize } \\
\text { d } \\
\text { Coefficients }\end{array}$ \\
Beta
\end{tabular}} & \multirow[t]{2}{*}{$\mathrm{T}$} & \multirow[t]{2}{*}{ Sig. } & \multicolumn{2}{|c|}{$\begin{array}{c}\text { Collinearity } \\
\text { Statistics }\end{array}$} \\
\hline & B & $\begin{array}{l}\text { Std. } \\
\text { Error }\end{array}$ & & & & $\begin{array}{c}\text { Toleranc } \\
\text { e }\end{array}$ & VIF \\
\hline (Constant) & 6.644 & 1.175 & & 5.655 & .000 & & \\
\hline $\mathrm{ROA}$ & .243 & .102 & 301 & 2.379 & .021 & .924 & 1.082 \\
\hline CR & .468 & .177 & .650 & 2.638 & .011 & .244 & 4.094 \\
\hline DER & -.256 & .144 & -.423 & $\begin{array}{c}- \\
1.783\end{array}$ & .081 & .264 & 3.791 \\
\hline SIZE & .380 & .134 & .520 & 3.875 & .039 & .793 & 1.261 \\
\hline
\end{tabular}

a. Dependent Variable: DPR

Sumber: SPSS 21 (Data diolah 2017)

Berdasarkan output SPSS yang dilihat pada tabel Collienarity Statistics menunjukkan bahwa nilai Tolerance keempat variabel lebih dari 0.10 dan VIF kurang dari 10, maka dapat disimpulkan bahwa tidak terjadi multikolinieritas antar variabel bebas.

3. Hasil Uji Heteroskedastisistas

Tabel 4.8 Hasil Uji Glajser

Coefficients $^{a}$

\begin{tabular}{|c|c|c|c|c|c|c|}
\hline & \multirow[t]{2}{*}{ Model } & \multicolumn{2}{|c|}{$\begin{array}{l}\text { Unstandardized } \\
\text { Coefficients }\end{array}$} & \multirow{2}{*}{$\begin{array}{c}\begin{array}{c}\text { Standardiz } \\
\text { ed } \\
\text { Coefficients }\end{array} \\
\text { Beta }\end{array}$} & \multirow[t]{2}{*}{$\mathrm{T}$} & \multirow[t]{2}{*}{ Sig. } \\
\hline & & B & Std. Error & & & \\
\hline \multirow{5}{*}{1} & (Constant) & $\begin{array}{c}-1.012 \mathrm{E}- \\
013\end{array}$ & 1.175 & & .000 & 1.000 \\
\hline & ROA & .000 & .102 & .000 & .000 & 1.000 \\
\hline & CR & .000 & .177 & .000 & .000 & 1.000 \\
\hline & DER & .000 & .144 & .000 & .000 & 1.000 \\
\hline & SIZE & .000 & .434 & .000 & .000 & 1.000 \\
\hline
\end{tabular}




\section{a. Dependent Variable: AbsUt}

Sumber: SPSS 21 (Data diolah 2017)

Berdasarkan output SPSS yang dilihat pada tabel Uji Glejser menghasilkan nilai signifikan dari keempat variabel sebesar 1,000 lebih besar dari dari 0,05 artinya tidak terjadi heterokedastisitas.

4. Hasil Uji Autokorelasi

Tabel 4.9 Hasil Uji Autokorelasi

Model Summary

\begin{tabular}{|l|r|r|r|r|r|}
\hline Model & \multicolumn{1}{|c|}{$\mathrm{R}$} & R Square & $\begin{array}{c}\text { Adjusted R } \\
\text { Square }\end{array}$ & $\begin{array}{c}\text { Std. Error of } \\
\text { the Estimate }\end{array}$ & $\begin{array}{c}\text { Durbin- } \\
\text { Watson }\end{array}$ \\
\hline 1 & $.708 \mathrm{a}$ & .658 & .599 & .48345 & 2.049 \\
\hline
\end{tabular}

a. Predictors: (Constant), SIZE, ROA, DER, CR

b. Dependent Variable: DPR

Sumber: SPSS 21 (Data diolah 2017)

Berdasarkan output SPSS yang telah dilakukan menunjukkan bahwa Nilai DU dan DL bisa diperoleh dari tabel statistic Durbin Watson. Dengan k=4 dan N=55 dan standar signifikan 5\% maka di dapat nilai DU sebesar 1.7240 dan DL sebesar 1.4136. Jadi nilai 4-DU $=2.276$ dan $4-\mathrm{DL}=2.5864$. Dari output di atas, dapat kita lihat nilai DW sebesar 2.049. Karena nilai DW terletak di antara DU dan 4-DU $(1.7240<$ $2.049<2.276$ ), sehingga dapat disimpulkan bahwa tidak terjadi autokorelasi.

\section{Hasil Uji Regresi Linear Berganda}

\section{Tabel 4.10 Hasil Perhitungan Regresi Berganda}

Coefficients ${ }^{a}$

\begin{tabular}{|c|c|c|c|c|c|c|}
\hline \multirow{2}{*}{\multicolumn{2}{|c|}{ Model }} & \multicolumn{2}{|c|}{$\begin{array}{c}\text { Unstandardized } \\
\text { Coefficients }\end{array}$} & \multirow{2}{*}{$\begin{array}{c}\text { Standardize } \\
\mathrm{d} \\
\text { Coefficients }\end{array}$} & \multirow[t]{2}{*}{$\mathrm{T}$} & \multirow[t]{2}{*}{ Sig. } \\
\hline & & B & $\begin{array}{l}\text { Std. } \\
\text { Error }\end{array}$ & & & \\
\hline \multirow{5}{*}{1} & (Constant & 6.644 & 1.175 & & 5.655 & .000 \\
\hline & ROA & .243 & .102 & .301 & 2.379 & .021 \\
\hline & CR & .468 & .177 & .650 & 2.638 & .011 \\
\hline & DER & -.256 & .144 & -.423 & -1.783 & .081 \\
\hline & SIZE & .380 & .134 & .520 & 3.875 & .039 \\
\hline
\end{tabular}

a. Dependent Variable: DPR

Sumber: SPSS 21 (Data diolah 2107)

Setelah dilakukan pengolahaan data dengan SPSS di atas diperoleh nilai koefisien masing-masing variabel, serta didapat persamaan regresi sebagai berikut:

Kebijakan Dividen $=6,644+(0,243 \mathrm{ROA})+(0,468 \mathrm{CR})+(-0,256 \mathrm{DER})+(0,380$

$$
\text { Size) }+ \text { e. }
$$


Nilai konstanta (a) adalah 6,644; ini dapat diartikan jika Return On Asset, Current Ratio, Debt to Equity Ratio dan size nilainya adalah 0, maka Dividend Payout Ratio nilainya sebesar 6,644. Nilai koefisien regresi variabel Return On Asset (b1) bernilai positif, yaitu 0,243. Nilai koefisien regresi variabel Current Ratio (b2) bernilai positif, yaitu 0,468. Nilai koefisien regresi variabel Debt to Equity Ratio (b3) bernilai negatif, yaitu $-0,256$. Nilai koefisien regresi variabel size (b4) bernilai positif, yaitu 0,380 .

\section{Hasil Uji Koefisien Determinasi $\left(R^{2}\right)$}

Tabel 4.11 Hasil Uji Koefisien Determinasi $\left(\mathbf{R}^{2}\right)$ Model Summaryb

\begin{tabular}{|l|r|r|r|c|}
\hline Model & R & R Square & $\begin{array}{c}\text { Adjusted R } \\
\text { Square }\end{array}$ & $\begin{array}{c}\text { Std. Error of the } \\
\text { Estimate }\end{array}$ \\
\hline 1 & $.708^{\mathrm{a}}$ & .658 & .599 & .48345 \\
\hline
\end{tabular}

a. Predictors: (Constant), SIZE, ROA, DER, CR

b. Dependent Variable: DPR

Sumber: SPSS 21 (data diolah 2017)

Berdasarkan output SPSS menunjukkan ata nilai Adjusted $R^{2}$ menunjukkan angka $0,599 \times 100 \%=59,9 \%$. Hal ini mengindikasikan bahwa kontribusi variabel independen yaitu profitabilitas (Return On Asset), likuiditas (Current Ratio), leverage (Debt to Equity Ratio), dan ukuran prusahaan (Size) terhadap variabel dependen yaitu kebijakan dividen (Dividend Payout Ratio) adalah 59,9 \% sedangkan 40,1\% dipengaruhi faktor lain seperti nilai perusahaan, pertumbuhan perusahaan, keputusan investasi, dan masih banyak faktor lain yang tidak masuk ke dalam model penelitian.

\section{E. Hasil Uji Hipotesis}

1. Hasil Uji Statistik F

Tabel 4.12 Hasil Uji Statistik F ANOVA ${ }^{a}$

\begin{tabular}{|c|c|c|c|c|c|c|}
\hline \multicolumn{2}{|c|}{ Model } & $\begin{array}{l}\text { Sum of } \\
\text { Squares }\end{array}$ & Df & $\begin{array}{l}\text { Mean } \\
\text { Square }\end{array}$ & $\mathrm{F}$ & Sig. \\
\hline \multirow{3}{*}{1} & Regression & 2.562 & 4 & \multirow{3}{*}{$\begin{array}{l}.640 \\
.147\end{array}$} & \multirow[t]{3}{*}{4.356} & \multirow[t]{3}{*}{$.004^{\mathrm{b}}$} \\
\hline & Residual & 7.352 & 50 & & & \\
\hline & Total & 9.913 & 54 & & & \\
\hline
\end{tabular}

a. Dependent Variable: DPR

b. Predictors: (Constant), SIZE, ROA, DER, CR

Sumber: SPSS 21 (Data diolah 2017)

Berdasarkan output SPSS nilai $\mathrm{F}_{\text {Hitung }}$ sebesar $4.356>\mathrm{F}_{\text {Tabel }}$ sebesar 2.54 dengan tingkat signifikan lebih rendah dari tingkat kesalahan $(0,04<0,05)$. Hal ini menunjukkan bahwa profitabilitas (Return On Asset), likuiditas (Current Ratio), 
leverage (Debt to Equty Ratio), dan ukuran perusahaan (Size) secara simultan mempengaruhi kebijakan deviden (Devidend Payout Ratio).

2. Hasil Uji Statistik $\mathrm{t}$

Tabel 4.13 Hasil Uji Statistik $t$

Berdasarkan analisis regresi pada tabel diatas menujukkan hasil uji t pengaruh variabel inde

\begin{tabular}{|c|c|c|c|c|c|c|}
\hline \multirow{2}{*}{\multicolumn{2}{|c|}{ Model }} & \multicolumn{2}{|c|}{$\begin{array}{c}\text { Unstandardized } \\
\text { Coefficients }\end{array}$} & \multirow{2}{*}{$\begin{array}{c}\begin{array}{c}\text { Standardize } \\
\mathrm{d}\end{array} \\
\text { Coefficients }\end{array}$} & \multirow{2}{*}{$\mathrm{T}$} & \multirow{2}{*}{ Sig. } \\
\hline & & B & $\begin{array}{l}\text { Std. } \\
\text { Error }\end{array}$ & & & \\
\hline \multirow{5}{*}{1} & (Constant & 6.644 & 1.175 & & 5.655 & .000 \\
\hline & ROA & .243 & .102 & .301 & 2.379 & .021 \\
\hline & CR & .468 & .177 & .650 & 2.638 & .011 \\
\hline & DER & -.256 & .144 & -.423 & -1.783 & .081 \\
\hline & SIZE & .380 & .134 & .520 & 3.875 & .039 \\
\hline
\end{tabular}

a. Dependent Variable: DPR

Sumber: SPSS 21 (Data diolah 2107)

a. Pengaruh profitabilitas terhadap kebijakan dividen

Berdasarkan uji statistik $\mathrm{t}$ pada tabel diatas variabel profitabilitas yang di ukur dengan Return On Asset (ROA) menunjukkan nilai koefisien sebesar 0,243 dan nilai $t_{\text {Hitung }}$ sebesar $2.379>t_{\text {Tabel }}$ sebesar 2.008 dengan nilai signifikan sebesar $0,021<0,05$. Maka dapat disimpulkan bahwa $\mathrm{H}_{\mathrm{o}}$ ditolak dan $\mathrm{H}_{\mathrm{a}}$ diterima, artinya profitabilitas berpengaruh positif dan signifikan terhadap kebijakan deviden.

b. Pengaruh likuiditas terhadap kebijakan dividen

Berdasarkan uji statistik $\mathrm{t}$ pada tabel diatas, variabel likuiditas yang diukur dengan Current Ratio (CR) menunjukkan nilai koefisien sebesar 0,468 dan nilai $t_{\text {Hitung }}$ sebesar 2,6381 $>\mathrm{t}_{\text {Tabel }}$ sebesar 2.008 dengan nilai signifikan sebesar 0,011<0,05. Maka dapat disimpulkan bahwa $\mathrm{H}_{\mathrm{o}}$ ditolak dan $\mathrm{H}_{\mathrm{a}}$ diterima, artinya likuiditas berpengaruh positif dan signifikan terhadap kebijakan deviden.

c. Pengaruh leverage terhadap kebijakan dividen

Berdasarkan uji statistik $\mathrm{t}$ pada tabel diatas, variabel leverage yang diukur dengan Debt to Equity Ratio (DER) menunjukkan nilai koefisien sebesar -0,233 dan nilai $\mathrm{t}_{\text {Hitung }}$ sebesar $-1,783<\mathrm{t}_{\text {Tabel }}$ sebesar 2.008 dengan nilai signifikan sebesar $0,81>0,05$. Maka dapat disimpulkan bahwa $\mathrm{H}_{\mathrm{o}}$ diterima dan $\mathrm{H}_{\mathrm{a}}$ ditolak, artinya leverage berpengaruh negatif dan tidak signifikan terhadap kebijakan deviden.

d. Pengaruh ukuran prusahaan terhadap kebijkan dividen

Berdasarkan uji statistik $\mathrm{t}$ pada tabel diatas, variabel ukuran perusahaan yang diukur dengan In Total Akativa menunjukkan nilai koefisien sebesar 0,380 dan nilai $\mathrm{t}_{\text {Hitung }}$ sebesar $3.875>\mathrm{t}_{\text {Tabel }}$ sebesar 2.008 dengan nilai signifikan sebesar 0,038< 0,05. Maka dapat disimpulkan bahwa $\mathrm{H}_{\mathrm{o}}$ ditolak dan $\mathrm{H}_{\mathrm{a}}$ diterima, artinya ukuran perusahaan berpengaruh positif dan signifikan terhadap kebijakan deviden. 


\section{KESIMPULAN DAN IMPLIKASI}

\section{A. Kesimpulan}

Berdasarkan analisis data dan pembahasan hasil penelitian, dapat ditarik kesimpulan sebagai berikut:

1) Variabel profitabilitas, likuiditas, leverage, dan ukuran perusahaan secara simultan berpengaruh terhadap kebijakan dividen sehingga hipotesis pertama diterima.

2) Variabel profitabilitas (Return On Asset) berpengaruh positif dan signifikan terhadap kebijakan dividen (Dividend Payout Ratio) sehingga hipotesis kedua diterima.

3) Variabel likuiditas (Current Ratio) berpengaruh positif dan signifikan terhadap kebijakan dividen (Dividend Payout Ratio) sehingga hipotesis ketiga diterima.

4) Variabel Leverage (Debt to Equity Ratio) berpengaruh negatif dan tidak signifikan terhadap (Dividend Payout Ratio) sehingga hipotesis keempat dierima.

\section{B. Implikasi Penelitian}

Berdasarkan kesimpulan dari hasil penelitian diatas maka dapat ditarik implikasi sebagai berikut:

1) Hasil penelitian yang dilakukan pada perusahaan yang terdaftar di Jakarta Islamic Index (JII) periode tahun 2011-2015 disimpulkan bahwa profitabilitas yang diukur dengan Return On Asset (ROA), likuiditas diukur dengan Current Ratio (CR), leverage yang diukur dengan Debt to Equity Ratio (DER), dan ukuran perusahaan diukur dengan Logaritma natural dari total aktiva perusahaan berpengaruh secara simultan terhadap kebijakan dividen yang diukur dengan Dividend Payout Ratio (DPR).

2) Hasil penelitian yang dilakukan pada perusahaan yang terdaftar di Jakarta Islamic Index (JII) periode tahun 2011-2015 disimpulkan bahwa profitabilitas yang diukur dengan Return On Asset (ROA) berpengaruh positif dan signifikan terhadap kebijakan dividen yang diukur dengan Dividend Payout Ratio (DPR). Hal demikian membuktikan bahwa keuntungan yang diperoleh oleh perusahaan merupakan sinyal yag positif bagi para pemegang saham untuk memperoleh dividen yang diharapkan. Semakin besar keuntungan yang diperoleh oleh perusahaan, maka akan memberikan dividen yang besar pula terhadap para pemegang saham.

3) Hasil penelitian kedua diketahui bahwa likuiditas yang diukur dengan Current Ratio (CR) mempunyai pengaruh yang positif dan signifikan terhadap kebijakan dividen yang diukur dengan Dividend Payout Ratio (DPR). Tingkat likuiditas yang tinggi dapat menggambarkan kinerja perusahaan yang baik karena dengan tingkat likuiditas yang baik perusahaan akan lebih mudah untuk memenuhi kewajiban pembayaran dividen (sartono, 2001:114). 
Semakin tinggi tingkat likuiditas semakin besar pula tingkat kemampuan perusahan untuk membayarkan dividen kepada para pemegang saham.

4) Hasil penelitian ketiga diketahui bahwa leverage yang diukur dengan Debt to Equity Ratio (DER) mempunyai pengaruh yang negatif dan tidak signifikan terhadap kebijakan dividen yang dikukur dengan Dividend Payout Ratio (DPR). Hal ini membuktikan bahwa semakin tinggi leverage maka akan menunjukkan semakin besar kewajiban yang dimiliki perusahaan, sehingga leverage dapat mempengaruhi tingkat pendapatan bersih yang tersedia bagi para pemegang saham, yang artinya semakin besar kewajiban perusahaan akan menurunkan kemampuan perusahaan dalam pembayaran dividen.

5) Hasil penelitian yang terkhir dikatahui bahwa ukuran prusahaan yang diproyeksikan dengan Logaritma natural dari total aktiva perusahaan memberikan hasil bahwa ukuran prusahaan berpengaruh positif dan singnifikan terhadap kebijakan dividen yang diukur dengan Divdend Payout Ratio (DPR). Perusahaan dengan ukuran yang besar cenderung memiliki suatu kemudahan dalam aksesnya menuju pasar modal. Tentu saja hal tersebut mempengaruhi fleksibilitas perusahaan besar tersebut dalam memperoleh dana dalam jumlah besar. Perolehan dana tersebut, dapat digunakan sebagai pembayaran dividen bagi pemegang sahamnya.

\section{DAFTAR PUSTAKA}

Ahmad, Rodoni dan Herni, Ali. Manajemen Keuangan. Penerbit Mitra Wacana Media, Jakarta, 2010.

Ayu, Ida A. Idawati dan Gede M. Sudiartha. Pengaruh Profitabilitas, Likuiditas dan Ukuran Perusahaan Terhadap Kebijakan Dividen Perusahaan Manufaktur di BEI. Jurnal UNUD Vol.3 No.6, Bali, 2014.

Bambang, Riyanto. Dasar-Dasar Pembelanjaan Perusahaan. Edisi Keempat, Cetakan Ke-7, Yogyakarta: BPFE, 2001.

Brigham, Huston. Dasar-dasar Manajemen Keuangan (Buku II, Edisi 10, Jakarta: Salemba Empat, 2006).

Chang, M., dan Rhee, K.R. Testing Trade Off and Pecking Order Predictions about Dividen ds and Debt, The Center for Research in Security Prices. Working Paper, p.1-38. 1990.

Chasanah, Amalia N. Faktor-faktor yang Mempengaruhi Dividend Payout Ratio (DPR) Pada Perusahaan yang Listed Di Bursa Efek Indonesia. Tesis, Universitas Diponegoro Semarang, 2008.

Darsono P, SE, SF, MA, MM. Manajemen Keuangan Pendekatan Praktis (Jakarta: Nusantara Consulting, 2009).

Eugene, Brigham F, Joel F. Houston. Manajemen Keuangan (Buku II, Edisi Kedelapan, Erlangga: Jakarta, 2001).

Harmono, Manajemen Keuangan, Jakarta: PT Bumi Aksara, 2011.

Hartono, Jogianto. sTeori Portofolio dan Analisis Investasi. Edisi Kedua, Yokyakarta: UPPN AMP YKPN, 2000. 
Hatta, Atika Jauhari. Faktor-Faktor Yang Mempengaruhi Kebijakan Dividen: Investigasi Pengaruh Teori Stakeholder. JAAI. Vol.6, No.2, hal.1-22, 2002.

Irham Fahmi. Analisis Laporan Keuangan. Bandung: Penerbit Alfabeta, 2012.

Ita Lopolusi. Analisis Faktor-faktor yang Mempengaruhi Kebijakan Dividen. JIM. Universitas Surabaya Vol.2, No.1, 2013.

Jensen M.C. \& W.H. Meckfing. "Theory of The Firm: Managerial Behavior, Agency Costs and Ownership Structure" Journal of Financial Economics 3 Q North-Holland Publishing Company, 1976.

Keown, Arthur J, dkk. Manajemen Keuangan Prinsip-Prinsip dan Aplikasi. Jakarta: Pearson Education Inc. 2005.

Kuncoro, Mudrajad. Metode Riset untuk Bisnis dan Ekonomi. Jakarta: Erlangga, 2003.

Nurhayati, Mafizatun. Profitabilitas, likuiditas, dan ukuran perusahaan pengaruhnya terhdap kebijakan dividen dan nilai perusahaan sector non jasa periode 2007-2010. Jurnal keuangan Bisnis Vol.5 No.2, Juli 2013.

Nuringsih, Kartika. Analisis Kepemilikan Manajerial, Kebijakan Hutang, ROA, Dan Ukuran Perusahaan Terhadap Kebijakan Dividen (Pada Perusahaan Manufaktur Di Bursa Efek Indonesia 1995-1996). Jurnal Akuntansi dan Keuangan Indonesia, Vol.2, No. 2, 2005.

Parmitasari, Rika Dwi Ayu, 2016, Ownership Structure, Financial Decisions And Their Impact On Firm Value: Jakarta Islamic Index, Man In India, 96 (11) : 4483-4502.

Prihantoro. Estimasi pengaruh dividen payout pada perusahaan publik di Indonesia. Jurnal Ekonomi dan Bisnis No.1 Jilid.8.p.7-14, 2003.

Rodoni, Ahmad dan Herni Ali. Manajemen Keuangan. Edisi Pertama, Jakarta: Mitra Wacana Media. 2010.S

Sandy, Ahmad dan Nur Fadjrih Asyik. Pengaruh Profitabilitas dan Likuiditas Terhadap kebijakan Dividen Kas pada Perusahaan Otomotif. Jurnal Ilmu dan Riset Akuntansi Vol.1 No.1. Jakarta: STIESA, Januari 2013.

Sudarsi, Sri. Analisis Faktor-faktor yang Mempengaruhi Dividen Payout Ratio pada Industri Perbankan yang Listed Di Bursa Efek Jakarta (BEJ). Jurnal Bisnis dan Ekonomi, 2002.

Sugiyono. Metode Penelitian Kuantitatif, Kualitatif, dan RED. Cetakan ke-23 Bandung: Alfabeta. 2016.

Suharli, Michell dan Sofyan F. Harahap. Studi Empiris Terhadap Faktor Penentu Kebijakan Jumlah Dividen. Media Riset Akuntansi, Auditing, dan Informasi. Vol.4, No.3, hal.223-245, 2004.

Sujoko dan Ugy Soebiantoro. Pengaruh Struktur Kepemilikan Saham, Leverange, Faktor Interen dan Fakator Ekstern Terhadap Nilai Perusahaan. Jurnal Manajemen dan Kewirausahaan, Vol. 9, No.1, 2007.

Syariati,A. The effect of Islamic Comercial Banks' Health and their Cost of Fund upon its Financing in Indonesia over 2005-2009.

Van Horne, James C. dan John M. Wachowicz, JR. Prinsip-prinsip Manajemen Keuangan. Buku 1 Edisi 12. Jakarta: Salemba Empat. 2005. 